\title{
Analysis of the Oral Health Conditions in Children from a Nursery in Manaus, Amazon - Brazil
}

\author{
Antônio Carlos Nogueira Brasil, Núbia da Costa Pantoja, Érica da Silva Carvalho, Eduardo Jorge \\ Sant'Ana Jorge Honorato, Ângela Xavier Monteiro, Sônia Maria Lemos, Tirza Almeida da Silva, Daniel \\ Cerdeira de Souza, Clarissa Santana Cruz, Luziane Vitoriano da Costa, Kenne Samara Andrade Martins, \\ Rômulo Chaves Pereira de Oliveira
}

\begin{abstract}
INTRODUCTION: For this work was necessary to make an epidemiological survey of preschool children studying in Nursery Children's House, an organization of social and religious assistance nonprofit. OBJECTIVES: The aim of this study was to make an epidemiological survey and know the reality of an unofficial age by WHO to 3-5 years of age, to compare and investigate if over the years the disease get more space. Perform DMF and compare with CPODS the city of Manaus, Northern Region, the Interior and National Average between the ages searching the literature studies that showed the same age group. MATERIAL AND METHODS: We used the DMF index for tooth decay. The study population consisted of pre-school at ages 3-5 years studying in Nursery Children's House, the examinations were performed by double examiners previously calibrated with the child sitting on a chair, on the premises of their own day care under the illumination of a white light flashlight positioned perpendicular to the teeth by the annotators. Material used was mirror clinical No 05, explorer with blunt tip, wooden spatula. RESULTS: The DMFT indexes House Child Day Care found the prevalence of caries of 2.47 to 3 years, 2.17 years and 2.97 for 4 to 5 years. CONCLUSION: It was established the prevalence of caries in children of the Creche, was promoted awareness and education about oral health and compared the results with other studies and national average.
\end{abstract}

Index Terms - Child development, Dental carie, Oral health.

\section{INTRODUCTION}

Oral health is an integral part of general health and is essential for quality of life. All individuals should have an oral health condition that allows them to speak, chew, recognize the taste of food, smile, live free of pain and discomfort, and relate to others without embarrassment [1]. In both developed and developing countries, the prevalence of dental caries has declined since the 1970s. In Brazil, there was a drop from 6.65 (1986) to 2.78 in 2003, at 12 years ,

Antônio Carlos Nogueira Brasil, Uninorte

Núbia da Costa Pantoja, Uninorte

Érica da Silva Carvalho, UEA - Amazonas State University - School of Health

Eduardo Jorge Sant'Ana Jorge Honorato, UEA - Amazonas State University - School of Health

Ângela Xavier Monteiro, UEA - Amazonas State University - School of Health

Sônia Maria Lemos, UEA - Amazonas State University - School of Health Tirza Almeida da Silva, UNIP - Psychology Department

Daniel Cerdeira de Souza, Federal University of Santa Catarina

Clarissa Santana Cruz, UEA - Amazonas State University - School of Health

Luziane Vitoriano da Costa, UNIP - Psychology Department

Kenne Samara Andrade Martins, UNIP - Psychology Department

Rômulo Chaves Pereira de Oliveira, UFAM - Federal University of Amazonas - MedSchool demonstrating a reduction of $58.2 \%$ [2]. However, it can be verified that this decline occurred along with a phenomenon known as polarization, characterized by the concentration of the highest caries rates in small population groups within the same country or region [3,6]. Dental caries are a multifactorial disease and in order to develop, it is necessary to interact under critical conditions of three primary factors represented by the host with susceptible teeth, oral colonization by cariogenic microorganisms and frequent consumption of fermentable carbohydrates [10]. Dental caries is still one of the most prevalent diseases in our country. According to the Brazil SB 2003 Project report, in relation to caries, Brazil reached the WHO targets for the year

${ }^{2} 2000$ only by the age of 12 , and in part this was due to the children of the South and Southeast regions [4]. ]. Still according to this survey, for the southeastern region of Brazil, there was a ceod of 2.50 at 5 years; 2.30 at 12 years and for the age group of 15 to 19 years an average of 5.94 was observed [14].

Among the possible causes for the aforementioned decline in caries disease rates are the large-scale use of fluoridated dentifrices, expansion of fluoridation of public water supply, improvements in the population's living conditions, changes in dietary patterns and changes in diagnostic criteria [5]. The knowledge of risk factors for dental caries allows the adaptation of oral health care and reorientation of expenses with prevention, thus respecting the principle of equity, since such factors have been frequently discussed, including social and behavioral factors [6]. Population-based or epidemiological studies such as PCO-D are needed to guide planning and decision-making in public health policies [7]. Through investigation of the health problems of a community, the focus that the public power will have will be better to combat and control more prevalent and wicked illnesses and diseases [8]. The CPO-D index is the most used until today since 1937, formulated by Klein and Palmer, with better reference for diagnoses and development of oral health actions [1].

The knowledge of the distribution and frequency of diseases provides better conditions of strategic planning leading to population health assistance, implementation of preventive methods and in health promotion [8]. The comparison of caries trends observed in each country makes it possible to explore the links between rates of caries occurring over time and more general aspects related to industrialization, human development and national oral health policies [6]. When referring the thought to the history 
of caries, there are three distinct moments of characterization of the disease in human societies. Although the caries accompany the human being since its prehistory, the pattern of illness in the primitive communities is characterized by a disease of low population impact, in quantitative terms and severity. Concomitant to the "civilizing" process, with the introduction of new eating and life habits, especially from growing industrialization and urbanization, caries becomes a violent and high prevalence disease, meaning a serious public health problem. In the last decade of the twentieth century, another important phenomenon in the disease is reported [19]. The fall in prevalence and severity, especially at twelve years of age, indicated a decreasing escalation of CPO-D index values (decayed, missing and filled teeth). It is one of the challenges of dentistry today: transforming its thinking, adapting it to the new social reality of disease [19].

In Brazil, most oral health programs have directed almost all of their resources over the years to schoolchildren according to the priorities established for public health. This has left secondary care to preschoolers [18]. The prevention of dental caries in preschool children is important, since the absence or low caries index in the deciduous dentition indicates a good prognosis for the permanent dentition [18]. The dental caries experience in the deciduous dentition is a strong predictor of the disease in the permanent dentition, and may suggest whether or not the oral environment is favorable to the development of the disease during the eruption of the first permanent teeth [18]. The individual characterization of possible factors involved in the etiology of dental caries allows the identification of individuals at risk, establishment of early diagnosis and adequate monitoring of individuals with previous caries experience. On the other hand, the identification of risk groups requires individual information regarding exposure to fluoride, oral hygiene habits, socioeconomic aspects, as well as results obtained from microbiological examinations [10] It is already known that caries is a sucrose-dependent disease and that social determinants of health will control its multiple factors [19]

The purpose was to show the various facets of the subject. The basis of the model presents the individuals and their particular characteristics of age, sex and genetic factors, which exert a positive or negative influence on their health status [11]. Then individual behavior and lifestyles are explicit and have a fundamental relation to the freedom that each individual has to make choices, it is free will that is influenced by the particular characteristics of the center of the figure, but which is also related to the social and community networks. In the next extract, the living and working conditions that the community has to enjoy and which influence the population's choice of food, healthy or unhealthy conditions of work or unemployment, health and housing conditions [11]. The last layer deals with the macro-determinants of health, the general socioeconomic, cultural and environmental conditions to which the community is exposed and which exert influence on the other layers (DAHLGREN and WHITEHEAD, 1991)

\section{OBJECTIVES}

To make an epidemiological survey and to know the reality of an unofficial age by the WHO from 3 to 5 years of age, to compare and investigate if over the years the disease gains more space. To perform the CPOD and to compare with the DMFTs of Manaus, Northern Region, State Interior and National Average among the ages searching in the literature works that showed the same age group.

\section{Methodology}

This research was submitted to the Research Ethics Committee of the Amazonas State University through the Brazilian Platform under the CAAE process: 42183415.4.0000.5016. Data collection took place after the release of the authorization and agreement with the direction of the day care center. The Informed Consent Form was delivered to the parents or guardians and only the children were enrolled with the DICT signed, determining the inclusion and exclusion criteria. An epidemiological study of dental caries was carried out. The study population consisted of pre-school children aged 3 to 5 years who attend the Casa da Criança Day Care Center, a non-profit social and religious assistance organization. Before the approach was performed on the children, they underwent an educational lecture in which they received oral hygiene instructions. The examinations were carried out by the pair of examiners, previously calibrated, with the child sitting on a chair, in the facilities of the day care center, under the lighting of a white light torch positioned by the noteers perpendicular to the teeth. Material used was clinical mirror n 05, exploratory probe with blunt tip, wooden spatula and sheets of CPOD. To evaluate the oral health conditions of schoolchildren, a DMFT index was used for dental caries. This index has been widely used in epidemiological surveys of oral health. It is an index recommended by the World Health Organization (WHO) to measure and compare the dental caries experience in populations, its value expressed the average of decayed, lost and obturated teeth in a group of individuals.

The WHO criteria from 1997, were followed, notably regarding the presence or not of dental caries in regions of fossils and fissures. In case of doubt, the criterion used for a crown to be considered carious was the evidence of caries lesion where the probe was able to penetrate the scar or without the probe could penetrate the fossil or fissure, but with evidence of undercut enamel. Dark spots restricted to these occlusal regions with enamel showing firmness to the probing were classified as a healthy tooth. A total of 210 children out of 250 were evaluated, 40 of whom did not correctly complete the Free and Informed Consent Form and were excluded from the study. The sample number was 210 children.

\section{RESULTS}

The relationship of DMFT with age showed that at 3 years DMFT presented 2.47 falling at 4 years to 2.17 and having a significant increase of 2.97 at five years of age.

The CPOD of Casa da Criança at age 5 is 2.97 a significant number when compared to the CPOD of the city of Manaus, 
which is 2.88. The average of the North region for the same age is of 3.37 being behind the average of the interior of the State of Amazonas with 3.74. The national average shows 2.43 DMFT

\section{DISCUSSION}

In relation to the age of schoolchildren, we realized that a daycare center where socioeconomic status weighs as a social determinant will find a high caries index with a strong tendency to grow according to the research. Studies focusing on early childhood follow the WHO criteria, defining caries from the cavitation stage, disregarding the incipient lesions and often neglecting their early establishment [13]. In the present study, the epidemiological profile of the population studied was analyzed and a mean DMFT of 2.97 was verified, while the national average for children in the 5-year age group and 2.43 according to the 2010 National Oral Health Survey The average of children in the day care center was below this reality because there is the dental care once a week depotencializando the action of the microorganisms causing carious lesions.

The mean DMFT in the city of Manaus is 2.88 [14] higher than the national average and higher than the average day care center children. Some localities in Brazil exhibit more favorable numbers of DMFT for the deciduous dentition are 1.88 for the preschoolers of Araçatuba in. [18], 1.98 for the children of 5 years of Teresina - PI [13] and more alarming surveys, such as the average of pre-schoolers in the interior of the State of Goiás, with CPOD of 4.93 [15] and 3.51 for the capital Boa Vista - RR [14]. The results may be correlated to the fact that the North Region does not have fluoridated water, contrary to LEI No. 6,050, dated May 24, 1974, which provides for the fluoridation of public water supply. The high caries index may also be related to socioeconomic factors, since the day care center is a social and religious entity where there are children of self-employed, street vendors, domestic workers and others who can not afford to study their children in a private network of teaching, the influence of this factor on the prevalence of caries has already been verified by several studies $[18,19]$. These children may not have access to the oral health service. In daycare there is dental care once a week, but it works in poor conditions.

\section{CONCLUSIONS}

A high prevalence of caries was found in the study population when all stages of injury were considered. Poor oral hygiene showed a positive association with the presence of caries in this age group. Social risk factors such as low parental education, low family income and inadequate diet are common to dental caries and other childhood illnesses and diseases. In addition, the children live in one of the cities of Brazil without having fluoridated water service for continuous use. The prevalence of caries in children in the day-care center was established, awareness and education in oral health was promoted, we taught the methods of brushing and we applied topical fluoride in children as a preventive measure of oral diseases.

\section{REFERENCES}

[1] Petersen PE. The World Oral Health Report 2003: continuous improvement of oral health in the 21st century - the approach of the WHO Global Oral Health Programme. Community Dent Oral Epidemiol 2003; 31 Suppl 1:3-23.9 (1)

[2] Tagliaferro E P S, Meneghim M C, Ambrosano G M B, Pereira A C, Sales-Peres S H C, Sales-Peres A, Bastos J R M. Distribution and prevalence of dental caries in Bauru, Brazil, 1976-2006. International dental journal.2008;58(2): 75-80. (2)

[3] Peres KGA, Bastos JRM, Latorre MRDO. Severidade de cárie em crianças e relação com aspectos sociais e comportamentais. Rev. Saúde Pública. 2000; 34 (4): 402-8.(3)

[4] Noro LRA, Roncalli AG, Mendes Júnior FIR, Lima KC. Incidência de cárie dentária em adolescentes em município do Nordeste brasileiro. Cad. Saúde Pública. 2009; 25(4): 783-90.(4)

[5] Baldani MH, Vasconcelos AGG, Antunes JLF. Associação do índice CPO-D com indicadores sócio-econômicos e de provisão de serviços odontológicos no Estado do Paraná, Brasil. Cad. Saúde Pública, 2004; 20(1): 143-52. (5)

[6] Narvai PC, Frazão P, Roncalli AG, Antunes JLF. Cárie dentária no Brasil: declínio, polarização, iniquidade e exclusão social. Rev Panam Salud Publica/Pan Am J Public Health. 2006; 19(6): 358-93.(6) H. Poor, An Introduction to Signal Detection and Estimation. New York: Springer-Verlag, 1985, ch. 4.

[7] Fejerskov O, Thylstrup A, Larsen MJ. Clinical and structural features and possible pathogenic mechanisms of dental fluorosis. Scand J Dent Res 1977; 85:510-34 (7)

[8] Weatherell JA, Deutsch D, Robinson C, Hallsworth AS. Assimilation of fluoride by enamel throughout the life of the tooth. Caries Res 1977; 11 Suppl 1:85-115. (8) C. J. Kaufman, Rocky Mountain Research Lab., Boulder, CO, private communication, May 1995.

[9] Den Besten PK. Biological mechanisms of dental fluorosis relevant to the use of fluoride supplements.Community Dent Oral Epidemiol 1999; 27:41-7. (9)

[10] Cortelli SC, Cortelli JR, Prado JS, Aquino DR, Jorge AOC. Fatores de risco a cárie e CPOD em crianças com idade escolar. Cienc. Odontol. Bras, São José dos Campos, V. 7, n 2, p. 75-82 abr/jun. 2004 (10)J. Jones. (1991, May 10).

[11] Carvalho ES, Associação entre lesões de esforços repetitivos (LER/DORT) em membros superiores e a saúde bucal./ Dissertação (Mestrado) - Faculdade de Odontologia de Bauru, Universidade de São Paulo 2011. 133p.: Il ; 30cm (11)

[12] Barros SG, Alves AC, Pugliese LS, Reis SRA. Contribuição ao estudo da cárie dentária em crianças de 0-30 meses. Pesqui Odontol Bras. V. 15 , n. 3, p. 215-222, jul./ set. 2001. (12)

[13] Moura LFAD, Moura MS, Toledo AO. Dental carries in children that participated in a dental program providing mother and child care. $\mathbf{J}$ Appl Oral Sci. 2006; 14: 53-60 (13)

[14] SB Brasil 2010: Pesquisa Nacional de Saúde Bucal: resultados principais / Ministério da Saúde. Secretaria de Atenção à Saúde. Secretaria de Vigilância em Saúde. - Brasília : Ministério da Saúde, 2012.116 p. : il. (14)

[15] Freire MCM, Pereira MF, Batista SMO, Borges MRS, Barbosa MI, Rosa AGF. Prevalência de cárie e necessidade de tratamento em escolares de 6 a 12 anos da rede pública de ensino. Rev Saúde Pública 1999; 33: 385-90 (15)

[16] Saliba NA, Orenha ES, Nakama L, Meneghin MC, Moimaz SAS. Prevalência de cárie dentária em crianças de 3 a 6 anos de idade, do município de Araçatuba-SP, 1996. Rev Odontol UNESP 1998; 27: 207-13. (16)

[17] Ueda EMO, Dezan CC, Frossard WTG, Salomão F, Morita MC. Prevalence of dental caries in 3- and 5-year-old children living in a small Brazilian city. J Appl Oral Sci. 2004; 12:34-8. (17)

[18] Garbin CAS, Chiba FY Artênio Garbin JI, Arcieri RM Prevalencia de cárie dentária em pré-escolares de escolas de educação infantil de Araçatuba, São Paulo. Rev Odontol de Araçatuba, 2011 v.32, n.2, p. 28-32. Jul/dez

[19] Gomes D, Da Ros MA. A etiologia da cárie no estilo de pensamento da ciência odontológica. Ciênc. Saúde coletiva [online]. 2008, vol.13, n.3, PP. 1081-1090, ISSN 1413-8123 (19) 